\title{
The Structure of Research Activity Development in Preparing Future Foreign Language Teachers
}

\author{
Baranova Yuliia \\ Assistant \\ National University of Life and Environmental Sciences of Ukraine (Kyiv, Ukraine) \\ Matviienko Olena \\ Doctor of Pedagogical Sciences, Professor \\ Dragomanov National Pedagogical University (Kyiv, Ukraine)
}

\begin{abstract}
This article deals with the problem of readiness formation for scientific research activity of future foreign language teachers. For this purpose, the authors investigated scientific literature and developed the structure of readiness formation, using modelling approach. The structure consists of five stages of professional training of future teachers of foreign languages to conduct the scientific research: objective, methodological, substantial, operationally-procedural, efficiently-diagnostic. The objective stage consists of the aim and task definition. The methodological stage is formed by methodological approaches and principles. The substantial stage includes the process of formation of the list of professional competences of the modern teacher of foreign languages. The operational-procedural stage consists of defining the pedagogical conditions and the stages of preparation for scientific research activity of future foreign language teachers. The pedagogical condition "stimulation of motivation for educational-cognitive activity" provides formation of value-motivational component and motivational criteria of readiness. Digital literacy and $21^{\text {st }}$ century skills development contribute formation of the cognitive component and cognitive-investigational criterion of readiness formation. Education through investigation and scientific-research work activation ensure the formation of the operational-procedural component and creative and activity oriented criterion. Depending on the degree of actualization of the abovementioned criteria and their indicators, we determine the system of the estimation of levels of readiness for scientific research of future foreign languages teacher: reproductive (low), structural (middle), reflexive-creative (high) levels, what represents the efficiently-diagnostic stage of readiness formation.
\end{abstract}

Key words: structure of readiness, readiness formation, scientific research, foreign language teacher.

In the current conditions of educational development, the system of scientific research activity, which is the basis for effective future specialists' training, becomes important. A crucial requirement for effective scientific activity is a readiness of future teachers for scientific research activity.

Analysis of recent research and publications. The theoretical issues of general readiness formation investigated $\mathrm{O}$. Kovalyova, K. Platonova, M. Levitova, O. Vedenova. The problem of professional readiness formation for pedagogical activity researched V. Slastyonin, N. Klokar, N. Denysova, L. Kondrashova. 
The essence and conditions of effective readiness formation for scientific research of future teachers was covered in the investigations by V. Borysov, L. Pet'ko, N. Stavrinova, N. Sychkova, G. Shyshkina, Z. Isayeva, H. Turchynova.

Due to the analysis of scientific sources on this problem we may define that nowadays there is no general opinion concerning the structure of readiness formation for scientific research activity in future foreign language teachers.

The purpose of the article is to define the main components of the structure of readiness formation (components, criteria and levels) for scientific research activity of future foreign language teachers.

Presenting main material. To achieve the goal of the article we use the modelling approach.

Modelling approach is widely used in modern pedagogical researches by scientists I. Bohdanova, N. Bulhakova, S. Savchenko, N. Kondakov, O. Matviienko, L. Novikova, etc.

In opinion of V. Krayevsky modelling is one of the theoretical methods which contributes learning the structure and mechanisms of the studying and educational processes, logical structures of studying material. Model - is a result of an abstract generalization of practical experience, but not direct result of experiment [3].

According to Collins English Dictionary model is a system that is being used and that people might want to copy in order to achieve similar results; a model of a system or process is a theoretical description that can help you understand how the system or process works, or how it might work [13].

A term "model" means a certain system (standard, example, character, construction), that represents certain properties and relationships with other system that is named "an original", and substitutes it to some extent.

The scientists V.Davidiv and O.Rakhimov define model as a material object or an object that appears in the process of thinking. In research it substitutes an object-original so that it's direct study provides new knowledges about an object-original [2].

Modelling procedure consists of several stages: actualization of the accumulated knowledges about the object of research and choosing from the variety of existent models one that the most adequately represents the essence of the investigated object [11;21]. 
According to the analyses of investigated scientific sources we may define the model of readiness formation for scientific research activity of future foreign language teachers as a complex of interrelated components of pedagogical process at every stage of higher education that provides students with the necessary level of readiness for scientific research activity.

The model of our research consists five stages of professional training future teachers of foreign languages to conduct the scientific research: objective, methodological, substantial, operationally-procedural, efficiently-diagnostic.

The objective stage consists the aim and task definition. The general aim of our research is to form readiness for scientific research activity of future foreign language teachers and the task is to form value-motivational, cognitive and operationally-procedural components.

The methodological stage is formed by methodological approaches and principles.

The methodological approach essentially aims to understand the subjective and changing world of human experience. To make sense of this world, and the phenomena that are encountered, individuals construct their own realities and interpretations for this purpose [14].

The developed pedagogical model is based on the competence approach, which is the principle one. A realization of the competence approach in the sphere of professional training helps to investigate a problem of training future foreign language teacher from a different perspective.

The basic idea of this approach in our research is that the essential result of teacher's education is not acquisition of separate knowledges, abilities and values but the capability and readiness (and the level of this readiness) of students to conduct scientific research.

A realization of personal and action related approach is implemented by taking into consideration the individual peculiarities of a future foreign language teacher and his/her possibilities in the process of individual educational activity.

An informational approach is based on the development and improvement of informational skills and digital literacy of future teachers for effective organization of the educational process, scientific research activity and professional communication.

A realization of investigative approach is performed by enhancing research skills of teachers which are necessary for qualitative and productive organization of scientific research during their future professional performance. 
Methodological principles are universally desirable instructional design features, motivated by theory and research findings, educational psychology, general educational curriculum design, and elsewhere, which show them either to be necessary for scientific research and language learning or facilitative of it $[10 ; 15]$.

The analysis of scientific sources allows us to distinguish and characterize next basic principles of the future foreign language teachers' preparation for scientific research activity: the systemic, the scientific, the educational-investigative, the integrity of educational process, the innovativeness, the individualization, the collaboration, the activity, the professional mobility, the variability, the creativity, the continuity principles [16].

The principles - are the final clauses, which contribute choosing the forms, methods and substance of education.

The systemic principle is the primary one, which provides that every phenomenon, process, object is correlated with other objects and processes, and form a single unit. The process of preparing future foreign language teachers for scientific research activity is considered a set of interrelated elements.

The scientific principle provides the conformity of the substance of education with the level of modern science development. This principle ensures the process of the future foreign language teachers' preparation for scientific research activity based on scientific knowledges.

The educational-investigative principle provides the engagement of future teachers of foreign languages to effective cognitive activity, development of creative potential of student, thinking culture education, possession of science methodology, investigative competencies and abilities formation.

The principle of educational process integrity is based on integrity and cooperation of educational and scientific activities of future teachers of foreign languages, when scientific activity complements educational and vice versa [1, p. 15; 16].

The principle of innovativeness envisages the integration of innovative, pedagogical and informative technologies, that provides better quality of future teachers of foreign languages preparation in accordance with the requirements of modern informative society.

The principle of individualization provides organization of educational process, when the future teacher of foreign languages has the opportunity to choose independently the forms, 
methods, educational tools and pedagogical technologies, depending on his/her individual capabilities, age, necessities and interests.

The principle of collaboration envisages development of subject-subjective relations between the participants of educational process, that are based on equivalence, respect, trust, responsibility, mutual help, self-actualization, self-development, self-realization.

According to the principle of activity, the future foreign language teachers' preparation for scientific research activity is based on the positive result of the personal activity of a student, that is aimed at the receipt of new knowledges, abilities, realization of pedagogical values [17].

The principle of professional mobility is based on the readiness and ability of future teachers of foreign languages to grasp the achievements of pedagogical technologies and philology, to implement knowledges into pedagogical practice, to react quickly on the innovations, to be engaged in the self-education and professional training.

The principle of variability is based on the ability in the process of professional preparation the future teachers of foreign languages to use innovative educational resources, various kinds and forms of educational materials' presentation, independent choice of individual educational plan, methods of tasks decision, time of studying.

The creativity principle envisages the capacity of future teacher of foreign languages to act creatively, the necessity in initiativeness, originality in tasks solving and ideas generation $[4 ; 6 ; 8 ; 9 ; 20]$.

The continuity principle is based on the desire of future teacher of foreign languages to permanent personal development, that contributes development and implementation the own trajectory of personal and professional improvement [1, p. 15].

The substantial stage includes the process of formation of the list of professional competences of the modern teacher of foreign languages. Special attention we pay to the innovative competences. The peculiarity of the substantial stage is its dynamism as the result of continuous changes in the professional and pedagogical activities of foreign language teacher due to fast development of linguistic and information society.

The concept "professional competence" (investigated by D. Ushakova, V. Miheev, J. Dasyuk) we understand as a complex personal resource, which allows cooperate effectively with the surrounding world in one or another professional sphere, for realization of which we need certain spectrum of professional competences. While the concept "professional 
competence of teacher of foreign languages" is determined as a system of cultural, discursive, strategic, linguistic and social-linguistic abilities, knowledges and skills, which gives an opportunity to the communication participants to co-operate effectively in certain socially defined communicative situations, for getting skills and ability to apply knowledges in psychology, pedagogics and methodology of foreign language teaching.

On the basis of analysis of scientific literature, we define key competences of teacher: pedagogical, psychological, reflexive, organizational, creative, investigative, native language communicative competences. In addition, the foreign language teacher must develop foreign language communicative competence, methodical, linguistic, literary, informational competences.

Taking into consideration the conditions of educational system development in modern informative society we define the key innovative competencies of the foreign language teacher: communicative (includes linguistic, pragmatic, social-linguistic knowledges and abilities), informational (includes informational knowledges and abilities), constructive (includes constructive abilities) and investigative (includes analytical-synthetical, diagnostical, prognostic-projective, creative-innovational abilities).

All this professional competencies future teacher of foreign languages may improve by taking part in individual (tutoring, distance education, self-education, virtually-methodical platform), collective (refresher courses, modal courses, conferences) and individually-collective (internship, scientific-applied project, informal refresher courses, consultations) forms of professional activities.

The operational-procedural stage consists of defining the pedagogical conditions and the stages of preparation for scientific research activity of future foreign language teachers. In our investigation we define five pedagogical conditions: stimulation of motivation for educational-cognitive activity, education through investigation, $21^{\text {st }}$ century skills development, digital literacy, scientific-research work activation.

The efficient-diagnostic stage is formed by the components, criteria and levels of readiness formation of future teachers.

The first pedagogical condition "stimulation of motivation for educational-cognitive activity" provides formation of value-motivational component and motivational criteria of readiness. 
The value-motivational component is presented by the system of the value orientations, professional values and motives. The motivational criterion includes next indicators as positive attitude of future teacher towards research activity; level of formed motivation; value orientations; commitment to scientific research; developed cognitive, creative and searching interests; tendency for independent and continuous development and perfection of knowledges; investigative style of thinking; orientation

on innovations, creativity.

Using cognitive, strong-willed, social and emotional methods of stimulation motivation [5, p. 105] for educational-cognitive activity influences positively on discovering identity of future teacher, his/her individual and creative development, aims determination in future professional activity.

Digital literacy and $21^{\text {st }}$ century skills development contribute formation of the cognitive component and cognitive-investigational criterion of readiness formation.

Cognitive component is presented by the system of analytical, prognostic, projective, reflexive, investigative skills. The cognitive-investigational criterion is based on the next indicators: the level of formed system of knowledges (investigative, methodical, psychologicalpedagogical, professional, philological); understanding the logic of scientific research; knowing the principles of research organization.

Education through investigation and scientific-research work activation ensure the formation of the operational-procedural component and creative and activity oriented criterion. The operational-procedural component consists of the complex of science and investigation oriented actions. The creative and activity oriented criterion is based on the next indicators: a level of formed research skills (communicative, investigative, analytical, organizational) necessary for realization of scientific researches; ability to search, accumulate, critically estimate information, forecast the ways of problem development; ability to apply effective technologies and models; ability to apply statistical methods correctly; ability to use facilities of information technologies).

Depending on the degree of actualization of the above-mentioned criteria and their indicators, we determine the system of the estimation of levels of readiness for scientific research of future foreign languages teacher: reproductive (low), structural (middle), reflexivecreative (high) levels, what represents the efficiently-diagnostic stage of readiness formation. 
Conclusions and prospects of research. On the basis of the analysis of the psychological and pedagogical literature we may determine that the readiness formation for scientific research activity of future foreign language teachers is a complex personal formation that ensures the effective functioning of scientific research activity and covers knowledges, skills, experience, individual peculiarities and attitudes towards scientific research activity. The components of readiness for scientific research activity are value-motivational, cognitive and operational-procedural. Further research of the problem we define in looking the ways of the readiness formation for scientific research activity of future foreign language teachers in practice.

\section{References}

1. Baranova Yu. V. Osoblyvosti pidgotovky maybutnih uchyteliv inozemnyh mov do naukovo-doslidnoyi roboty [The particularities of preparation of future foreign language teachers to scientific research in establishments of higher education]. Innjvatciyna pedagogika. 2019. Issue 13. T. 1. P. 13-16.

2. Davydov V.V., Rakhimov O.H. Teoreticheskiie $i$ metodologicheskiie osnovy modelirovaniya processa professionalnoy podgotovki specialista [Theoretical and methodological bases of modelling of professional specialist training] Inovacii v obrazovanii. 2002. No 2, P. 62-83.

3. Krayevsky V.V., Polonsky V.M. Metodologiia dlya pedagoga: teoriya i practica [Methodology for teacher: theory and practice]. Volgograd: Peremena, 2001. P. 268-269.

4. Matviienko O. Systema profesiinoi pidhotovky maibutnikh uchyteliv do proektnoi diialnosti [The system of professional training future teachers for project activities]. Humanitarnyi visnyk DVNZ "Pereiaslav-Khmelnytskyi derzhavnyi ped. universytet imeni Hryhoriia Skovorody". Dodatok 1 do Issue 5, Vol. III (54): Tematychnyi vypusk «Vyshcha osvita Ukrainy u konteksti intehratsii do yevropeiskoho osvitnoho prostoru». Kyiv: Hnozys, 2014. P. 424-431.

5. Nechiporenko M. Motyvaciya yak klyuchovy factor formuvannya gotovnosti maybutnih uchyteliv inozemnyh mov do profesiyno-osobystisnogo samorozvytku [Motivation as a key factor of readiness formation in future foreign language teachers for professional and individual self-development]. Naukovi zapysky Ternopilskogo natcionalnogo pedagogichnogo universytetu imeni Volodymyra Gnatyuka. Seriya: Pedagogika. 2017. No. 2. P. 102-109 URI: http://nbuv.gov.ua/UJRN/NZTNPU_ped_2017_2_16

6. Petko L.V. Vykhovnyi potentsial metodu sytuatsiinoho analizu ( Case study» method) u formuvanni profesiino oriientovanoho inshomovnoho navchalnoho seredovyshcha $v$ umovakh universytetu [Educational potential of the "Case study» method for the forming of the professionally oriented foreign language teaching environment in the conditions of university]. Naukovyi chasopys NPU imeni M.P.Drahomanova. Seriia 17. Teoriia i praktyka navchannia ta vykhovannia : zb. nauk. pr. ; za red. akademika V.I.Bondaria. Kyiv: Vyd-vo NPU imeni M.P.Drahomanova, 2015. Issue 27. P. 133-140. 
7. Petko L.V. Doslidnytska diialnist studentiv koledzhu yak odna z umov neperervnoi osvity [Research activity of students in the college as one of conditions of lifelong education]. Aktualni problemy navchannia ta vykhovannia liudei v intehrovanomu seredovyshchi: $\mathrm{zb}$. nauk. prats. Kyiv: Universytet «Ukraina». 2010. No. 7. P. 122-134.

8. Petko L.V. Napysannia $i$ zakhyst referativ inozemnoiu movoiu za profesiinym spriamuvanniam - odyn iz shliakhiv pidhotovky studentiv do navchannia u mahistraturi [Writing and defense of a report in foreign language (in the professional way) as one of the means of students' preparation for teaching in magistracy]. Naukovyi chasopys Natsionalnoho pedahohichnoho universytetu imeni M.P. Drahomanova. Seriia № 5. Pedahohichni nauky: realii ta perspektyvy. Issue 35 : zb. nauk. pr. Kyiv: Vyd-vo NPU imeni M.P. Drahomanova, 2012. P. 132-138.

9. Petko L.V. Shliakhy formuvannia inshomovnoi sotsiokulturnoi kompetentsii studentiv mystetskykh spetsialnostei VNZ u protsesi fakhovoi pidhotovky [The Ways of Formation of Foreign Language Socio-Cultural Competence of Students of Music-Pedagogical Specialties in Higher School in the Process of Professional Teaching]/ Problemy pidgotovky suchasnogo vchytelja: zb. nauk. pr. Umans'kogo derzhavnogo pedagogic]. Problemy pidhotovky suchasnoho vchytelia: zb. nauk. pr. Umanskoho derzh. ped. un-tu imeni Pavla Tychyny. 2012. Issue 6. Part 3. P. 57-62.

10. Turchynova H.V. Pidhotovka maibutnikh vchyteliv pryrodnychykh dystsyplin do doslidnytskoi diialnosti u protsesi navchannia inozemnoi movy za fakhom [Future Science teachers training for research activities in the process of foreign language teaching in the professional way] // Topical issues of education : Collective monograph. - Pegasus Publishing, Lisbon, Portugal, 2018. P. 70-84.

11. Yudin E. G. Systenmy podhod i princyp deyatelnosti : problemy sovremennoy nauki [Systemic approach and operating principle: problems of modern science]. Moskva : Nauka, 1978.

12. Bezlyudna V.V. Professional future teachers training of foreign languages in Ukraine: basic concepts and terms. GLOKALde. 2016. Vol. 2. No. 3. P. 12-22. DOI: http:// www.glokalde.com/pdf/issues/7/Article1.pdf

13. Colin's Dictionary.

URI: https://www.collinsdictionary.com/dictionary/english/model

14. Fitzgerald A. Methodological Approach and Design. In: Fitzgerald A. (eds) Science in Primary Schools. SensePublishers, Rotterdam, 2012.

15. Long, M. H. Methodological principles for language teaching. In M. H. Long \& C. J. Doughty (Eds.), The handbook of language teaching (pp. 373-394). Oxford: WileyBlackwell, 2009.

16. Matviienko O. Integration of fundamental and practical training future primary school teacher in the context of a new Ukrainian school. Perspectives of research and development: Collection of scientific articles. - SAUL Publishing Ltd, Dublin, Ireland, 2017. P. 147-150.

17. Matviienko O. Modern approaches to goal setting for teacher pedagogical activity / O. Matviienko // Topical questions of contemporary science : collection of scientific articles. - 
Aspekt Publishing of Budget Printing Center, Taunton, MA 02780, United States of America, 2017. - P. 452-456.

18. Matviienko Olena. Pedagogical situations and tasks as means of training for professional activity. Economics, management, law: challenges and prospects: Collection of scientific articles. Psychology. Pedagogy and Education. - Discovery Publishing House Pvt. Ltd., New Delhi, India. 2016. P. 204-208.

19. Matviienko Olena. Theoretical bases of teacher's professional formation. Economics, management, law: socio-economical aspects of development : Collection of scientific articles. Vol. 2. Psychology. Pedagogy and Education. Edizioni Magi Roma, Italy. 2016. P. 237-239.

20. Pet'ko Lyudmila. Developing students' creativity in conditions of university. Research: tendencies and prospects: Collection of scientific articles. - Editorial Arane, S.A. de C.V., Mexico City, Mexico, 2017. P. 272-276.

21. Yaremenko-Gasiuk O.O. Foreign language training of future vocational teachers in the information-educational environment // International scientific-practical conference "Forming of modern educational environment: benefits, risks, implementation mechanisms" (Tbilisi, September 29, 2017). Tbilisi: Baltija Publishing. 2017. P. 46-48.

\section{Translation of the Title, Abstract and References to the Author's Language}

\section{УДК 37.211 .24}

Баранова Ю.В., Матвіснко О.В. Структура формування готовності до науково-дослідної роботи у майбутніх вчителів іноземних мов.

У статті розглядається проблема формування у майбутніх вчителів іноземних мов готовності до науково-дослідної роботи. 3 цією метою авторами були досліджені наукові джерела з цього питання та розроблена структура формування готовності, застосовуючи метод моделювання. Структура формування готовності складається 3 п’яти етапів: иільового, методологічного, змістового, операщійно-процесуального, результативнодіагностичного. Цільовий етап передбачає визначення мети і завдання. На методологічному етапі визначаються методологічні підходи та принципи. Змістовий етап складається з формування ряду професійних компетенцій сучасного вчителя іноземних мов. Операційно-процесуальний етап передбачає визначення педагогічних умов та стадій підготовки майбутніх вчителів іноземних мов до науково-дослідної роботи. Педагогічна умова «стимулювання мотивачії до пізнавально-навчальної діяльності» забезпечує формування ціннісно-мотиваційного компонента і мотиваційного критерію сформованості готовності. Цифрова грамотність та розвиток навичок 21 століття сприяють формуванню когнітивного компоненту та когнітивно-дослідницькій критерї. Навчання як дослідження та активація науково-дослідної роботи сприяють формуванню операційно-процесуального компонента та креативно-діяльнісного критерія. Залежно від ступеня актуалізації вищезазначених критеріїв та їх показників, нами сформована система оцінки у майбутніх вчителів іноземних мов рівнів готовності до науководослідної роботи: репродуктивний (низький), конструктивний (середній) та рефлексивно-творчій (високий).

Ключові слова: структура готовності, формування готовності, науково-дослідна робота, вчителі іноземних мов. 


\section{Jimepamypa}

1. Баранова Ю. В. Особливості підготовки майбутніх учителів іноземних мов до науково-дослідної роботи в закладі вищої освіти. Інноващійна педагогіка. 2019. Вип. 13. Т. 1. 2019. С. 13-16.

2. Давыдов, В. В., Рахимов, О. Х. Теоретические и методические основы моделирования процесса профессиональной подготовки специалиста. Инновации в образовании, 2002. №2. С. 62-83.

3. Краевский, В. В., Полонский В. М. Методология для педагога: теория и практика. Волгоград: Перемена. 2001. С. 268-269.

4. Матвієнко О. Система професійної підготовки майбутніх учителів до проектної діяльності. Гуманітарний вісник ДВНЗ "Переяслав-Хмельницький державний педагогічний університет імені Григорія Сковороди". Додаток 1 до Вип. 5, Том III (54): Тематичний випуск «Вища освіта України у контексті інтеграції до європейського освітнього простору». Київ: Гнозис, 2014. С. 424- 431.

5. Нечепоренко М. Мотивація як ключовий фактор формування готовності майбутніх учителів іноземних мов до професійно-особистісного саморозвитку. Наукові записки Тернопільського нац. пед. ун-ту імені Володимира Гнатюка. Серія: Педагогіка. 2017. № 2. С. 102-109.

URI: http://nbuv.gov.ua/UJRN/NZTNPU_ped_2017_2_16

6. Петько Л.В. Виховний потенціал методу ситуаційного аналізу («Case study» method) у формуванні професійно орієнтованого іншомовного навчального середовища в умовах університету. Науковий часопис НПУ імені М.П.Драгоманова. Серія 17. Теорія і практика навчання та виховання : зб. наук. пр. ; за ред. академіка В.І.Бондаря. Київ: Вид-во НПУ імені М.П.Драгоманова, 2015. Вип. 27. С. 133-140.

7. Петько Л.В. Дослідницька діяльність студентів коледжу як одна 3 умов неперервної освіти. Актуальні проблеми навчання та виховання людей в інтегрованому середовищі: зб. наук. праць. Київ: Університет «Україна». 2010. № 7. С. 122-134.

8. Петько Л.В. Написання і захист рефератів іноземною мовою за професійним спрямуванням - один із шляхів підготовки студентів до навчання у магістратурі. Науковий часопис Національного педагогічного університету імені М.П. Драгоманова. Серія № 5. Педагогічні науки: реалії та перспективи. Вип. 35 : зб. наук. пр. Київ: Вид-во НПУ імені М.П. Драгоманова, 2012. С. 132-138.

9. Петько Л.В. Шляхи формування іншомовної соціокультурної компетенції студентів мистецьких спеціальностей ВНЗ у процесі фахової підготовки. Проблеми підготовки сучасного вчителя: зб. наук. пр. Уманського держ. пед. ун-ту імені Павла Тичини. 2012. Випуск 6. Ч. 3. С. 57-62.

10. Турчинова Г.В. Підготовка майбутніх вчителів природничих дисциплін до дослідницької діяльності у процесі навчання іноземної мови за фахом // Topical issues of education : Collective monograph. - Pegasus Publishing, Lisbon, Portugal, 2018. P. 70-84.

11. Юдин, Э. Г. 1978. Системный подход и принц̧ип деятельности : проблемь соврем. науки. Москва : Наука. 
12. Bezlyudna V. V. Professional future teachers training of foreign languages in Ukraine: basic concepts and terms. GLOKALde. 2016. Vol. 2. No. 3. P. 12-22. DOI: http:// www.glokalde.com/pdf/issues/7/Article1.pdf

13. Colin's Dictionary. URI: https://www.collinsdictionary.com/dictionary/english/model

14. Fitzgerald A. (2012) Methodological Approach and Design. In: Fitzgerald A. (eds) Science in Primary Schools. SensePublishers, Rotterdam

15. Long, M. H. (2009). Methodological principles for language teaching. In M. H. Long \& C. J. Doughty (Eds.), The handbook of language teaching (pp. 373-394). Oxford: Wiley-Blackwell.

16. Matviienko O. Integration of fundamental and practical training future primary school teacher in the context of a new Ukrainian school. Perspectives of research and development: Collection of scientific articles. - SAUL Publishing Ltd, Dublin, Ireland, 2017. P. $147-150$.

17. Matviienko O. Modern approaches to goal setting for teacher pedagogical activity / O. Matviienko // Topical questions of contemporary science : collection of scientific articles. Aspekt Publishing of Budget Printing Center, Taunton, MA 02780, United States of America, 2017. - P. 452-456.

18. Matviienko Olena. Pedagogical situations and tasks as means of training for professional activity. Economics, management, law: challenges and prospects: Collection of scientific articles. Psychology. Pedagogy and Education. - Discovery Publishing House Pvt. Ltd., New Delhi, India. 2016. P. 204-208.

19. Matviienko Olena. Theoretical bases of teacher's professional formation. Economics, management, law: socio-economical aspects of development : Collection of scientific articles. Vol. 2. Psychology. Pedagogy and Education. Edizioni Magi Roma, Italy. 2016. P. 237-239.

20. Pet'ko Lyudmila. Developing students' creativity in conditions of university. Research: tendencies and prospects: Collection of scientific articles. - Editorial Arane, S.A. de C.V., Mexico City, Mexico, 2017. P. 272-276.

21. Yaremenko-Gasiuk O.O. Foreign language training of future vocational teachers in the information-educational environment // International scientific-practical conference "Forming of modern educational environment: benefits, risks, implementation mechanisms" (Tbilisi, September 29, 2017). Tbilisi: Baltija Publishing. 2017. P. 46-48. 